\title{
Acute Pancreatitis and Diabetic Ketoacidosis in Accidental Hypothermia and Hypothermic Myxoedema
}

\author{
D. MACLEAN, J. MURISON, P. D. GRIFFITHS
}

British Medical fournal, 1973, 4, 757-761

\begin{abstract}
Summary
Serial serum amylase and blood glucose levels were measured in 68 hypothermic (rectal temperature $35^{\circ} \mathrm{C}$ or less) patients, including 15 who had hypothermic myxoedema (serum protein bound iodine $3.5 \mu \mathrm{g} / 100 \mathrm{ml}$ or less). Raised amylase levels were found in 34 patients and probably reflected a mild acute pancreatitis. The high amylase levels correlated with low arterial $\mathrm{PO}_{2}$ levels and significantly with high arterial $\mathrm{PCO}_{2}$ levels and the base deficit but not with the severity or duration of the hypothermia. The acute pancreatitis does not explain why hypothermic patients with myxoedema have a poorer prognosis than those who are euthyroid. The pancreatitis occasionally contributed to the development, sometimes delayed, of diabetic ketoacidosis, blood glucose levels of over $120 \mathrm{mg} / 100 \mathrm{ml}$ being found in 20 patients. There was a significant correlation between the raised serum amylase levels and the hyperglycaemia. Hypoglycaemia, sometimes profound, was found in 12 patients.
\end{abstract}

\section{Introduction}

Acute pancreatitis occurring after induced hypothermia in patients with cancer was first noted at necropsy (Sano and Smith, 1940; Smith, 1940). More than $80 \%$ of patients dying from accidental hypothermia may have gross pancreatic changes varying from the occasional focus of fat necrosis to frank haemorrhagic pancreatitis with fat necrosis of the immediately adjacent tissues. If there have been recurrent episodes of hypothermia chronic pancreatitis may also be found (EmslieSmith, 1958; Duguid et al., 1961; Read et al., 1961; Prescott et al., 1962; Murphy and Faul, 1963; Mant, 1969). The mechanism of production of these lesions is unclear (Holmes and Emslie-Smith, 1961; Read et al., 1961) though intravascular sludging may play a part (Duguid et al., 1961).

Raised serum amylase levels are commonly found in patients with accidental hypothermia (Duguid et al., 1961; Holmes and Emslie-Smith, 1961; Read et al., 1961; Prescott et al., 1962; Murphy and Faul, 1963; Jones et al., 1966; McKean et al., 1970). Such high levels, usually reverting to normal in about a week (Holmes and Emslie-Smith, 1961; Murphy and Faul, 1963), may be found without the usual clinical manifestations of acute pancreatitis which occur in euthermic patients (Jones $e t$ al., 1966).

Hyperglycaemia, too, is common but not invariable in patients with accidental hypothermia (Alexander, 1945; Fruehan, 1960; Duguid et al., 1961; Prescott et al., 1962; Murphy and Faul, 1963), and occasionally exceedingly high blood sugar levels are found (Laufman, 1951; Duguid et al., 1961; Murphy and Faul, 1963). This hyperglycaemia has been attributed to an increased rate of hepatic glycogen breakdown during the initial stages of exposure followed by a decrease in the peripheral utilization of glucose as lower body temperatures are reached

University of Dundee

D. MACLEAN, PH.D., M.R.C.P., Lecturer in Medicine

J. MURISON, L.R.I.C., Chief Technician

P. D. GRIFFITHS, M.D., M.R.c.PATH., Professor of Clinical Chemistry
(Fruehan, 1960) and to profound stimulation of the suprarenal glands (Laufman, 1951).

Insulin release from the pancreas is inhibited by hypothermia itself (Curry and Curry, 1970; Baum and Porte, 1971) but it is not known whether the acute pancreatitis which is sometimes associated with accidental hypothermia and hypothermic myxoedema contributes further to the hyperglycaemia. None the less, even in uncomplicated diabetic ketoacidosis hypothermia is recognized as a cause of death (Soler et al., 1973).

\section{Patients and Methods}

Two groups of hypothermic (deep rectal temperature $35^{\circ} \mathrm{C}$ or less) patients were studied-53 euthyroid patients (table I) and 15 patients with serum protein bound iodine (P.B.I.) levels of $3.5 \mu \mathrm{g} / 100 \mathrm{ml}$ or less (table II) who were considered to be cases of hypothermic myxoedema (Sprunt et al., 1970). The associated disorders found in these patients and other clinical and biochemical data are shown in tables I, II, and III.

Many of the patients included here were mentioned in previous reports on the current accidental hypothermia study in the Dundee area (Maclean et al., 1968, 1973; Sprunt et al., 1970).

Regardless of the severity of their hypothermia or of their clinical symptoms all the patients were given intensive nursing care and their medical management was supervised by one of us (D.M.). The basic medical management of the hypothermia in both the euthyroid and hypothyroid groups was the same. All the patients were allowed to rewarm spontaneously through their own metabolic processes and without any additional active rewarming aids, each patient being placed in a room at 26.4 $32 \cdot 2^{\circ} \mathrm{C}$ and insulated against further heat loss by a covering of a sheet or one or two blankets. Oxygen therapy and artificial respiration were confined to a few patients and antibiotics were given only to those with clinical or radiological evidence of infection during or after recovery from their hypothermic episode. Intravenous fluids were not routinely used and the early correction of acid-base and ionic imbalances was undertaken in only a few instances. Steroids were not generally used (Sprunt et al., 1970). Thyroid hormone was not used in the euthyroid patients, but in those with hypothermic myxoedema failure to rewarm at a satisfactory rate over 12 hours was considered a positive indication for its use. Other drugs were not used routinely or generally though intravenous frusemide with or without digoxin was used to treat pulmonary oedema when it was present. In general any treatment given was determined by clinical problems other than the hypothermia. Thus the respective numbers of euthyroid and hypothyroid patients so treated were as follows: no treatment 28,5 ; antibiotics 13,5 ; hydrocortisone 7,2 ; digoxin 3,1 ; frusemide 4,2 ; potassium supplements 3,2 ; artificial respiration 1,0 ; oxygen 3,0 ; and intravenous fluids, etc., not controlled by central venous pressure measurements-plasma 1, 0 ; packed cells 1,0 ; saline 5,1 ; dextrose 7,1 ; bicarbonate or lactate 4,3 ; and insulin 2,1 .

The biochemical estimations were performed serially in each patient. Serum P.B.I. and urea levels were estimated by standard autoanalyser techniques and the acid-base status was assessed using the Astrup technique. The serum amylase levels were determined by a method involving the degradation of the starch fraction amylose (Street and Close, 1956, 1958) and the values obtained multiplied by 3.1 to convert them to Somogyi units (King, 1965). Blood glucose was assayed by the Auto Analyzer N2B-II methodology. 
TABLE I-Clinical and Biochemical Data on Hypothermic Euthyroid Patients

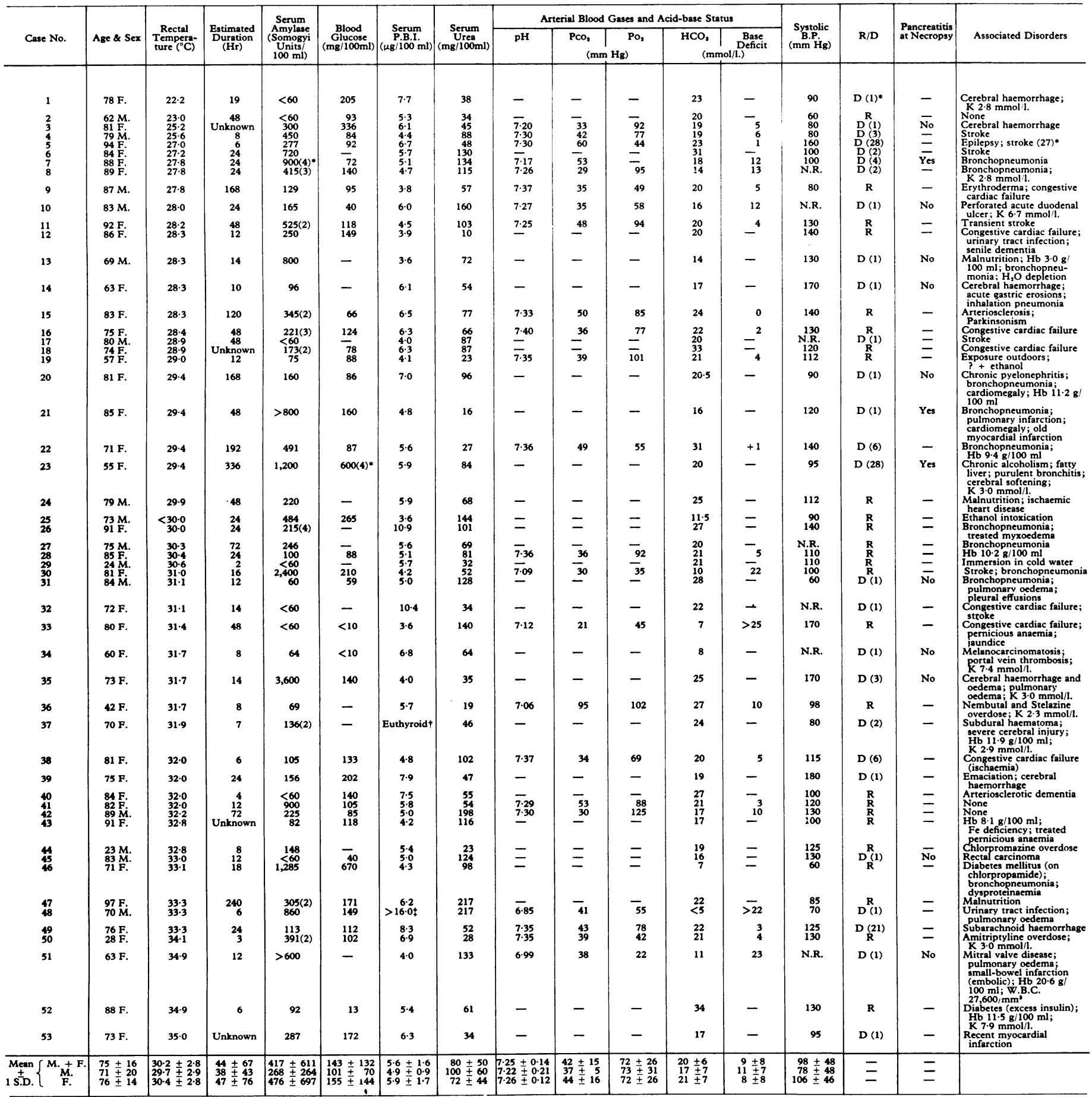

* Pisures in parentheses refer to dayy after admission or day of test.

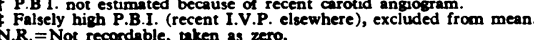

\section{Results}

Of the 53 euthyroid hypothermic patients 28 had serum amylase levels above the normal range-that is, over 200 Somogyi units/ $100 \mathrm{ml}$-but in only 11 did the values exceed 550 Somogyi units/ $100 \mathrm{ml}$ and suggest the diagnosis of acute pancreatitis (Wilkinson, 1962). Six patients with hypothermic myxoedema had raised amylase levels and two of these had levels compatible with acute pancreatitis. No patient with serum amylase values compatible with a diagnosis of acute pancreatitis had signs of an "acute abdomen." In each group the mean amylase level was higher for women than for men, but this difference was not significant. The mean amylase level in the euthyroid group was greater than that for the patients with hypothermic myxoedema, but this difference was not significant.

In all 68 patients the peak recorded serum amylase levels correlated with low $\mathrm{Po}_{2}(\mathrm{P}<0 \cdot 10)$ and high $\mathrm{PCO}_{2}(\mathrm{P}<0.001)$ levels and with the base deficit in the arterial blood $(P<0.05)$. No significant correlation emerged between the peak serum amylase levels and the patient's age or rectal temperature or the estimated duration of the hypothermia before the patient's admission to hospital. Similarly there was no significant correlation between the serum amylase levels and the serum P.B.I., serum urea, arterial blood $\mathrm{pH}$ or bicarbonate levels, or systolic blood pressure.

The mean amylase value $( \pm 1$ S.D.) in the patients dying 
TABLE II-Clinical and Biochemical Data on Hypothermic Hypothyroid Patients

\begin{tabular}{|c|c|c|c|c|c|c|c|c|c|c|c|c|c|c|c|c|}
\hline \multirow[b]{2}{*}{ Case No. } & \multirow[b]{2}{*}{ Age \& Sex } & \multirow[b]{2}{*}{$\begin{array}{l}\text { Rectal } \\
\text { Tempera- } \\
\text { ture ( }\left({ }^{\circ} \mathrm{C}\right)\end{array}$} & \multirow[b]{2}{*}{$\begin{array}{c}\text { Estimated } \\
\text { Duration } \\
(\mathrm{Hr})\end{array}$} & \multirow{2}{*}{$\begin{array}{c}\text { Serum } \\
\text { Amylase } \\
\text { (Somogyi } \\
\text { Unitss } \\
100 \mathrm{ml})\end{array}$} & \multirow[b]{2}{*}{$\underset{\left.\begin{array}{c}\text { Blood } \\
\text { Glucose } \\
(\mathrm{mg} / 100 \mathrm{ml})\end{array}\right)}{\mid}$} & \multirow[b]{2}{*}{$\left|\begin{array}{c}\text { Serum } \\
(\mu \mathrm{B} . \mathrm{I} . \\
(\boldsymbol{B} / \mathbf{1 0 0} \mathrm{ml})\end{array}\right|$} & \multirow[b]{2}{*}{$\underset{\begin{array}{c}\text { Serum } \\
\text { Urea } \\
(\mathbf{m g} / 100 \mathrm{ml})\end{array}}{\mid}$} & \multicolumn{5}{|c|}{ Arterial Blood Gases and Acid-base Status } & \multirow[b]{2}{*}{$\begin{array}{c}\text { Systolic } \\
\text { B.P. } \\
(\mathbf{m m} \mathbf{~ H g})\end{array}$} & \multirow[b]{2}{*}{$\mathbf{R} / \mathbf{D}$} & \multirow[b]{2}{*}{$\begin{array}{l}\text { Pancreatitis } \\
\text { at Necropsy }\end{array}$} & \multirow[b]{2}{*}{ Associated Disorders } \\
\hline & & & & & & & & $\mathrm{pH}$ & $\begin{array}{r}\mathrm{Pco}_{2} \\
(\mathrm{mn}\end{array}$ & $\begin{array}{l}\mathrm{Po}_{2} \\
\mathrm{Hg})\end{array}$ & $\begin{array}{r}\mathrm{HCO}, \\
(\mathrm{m}\end{array}$ & \begin{tabular}{|c|c|} 
Base \\
Dl/1.)
\end{tabular} & & & & \\
\hline 54 & $71 \mathrm{~F}$. & $26 \cdot 7$ & 8 & 261 & - & $<2 \cdot 0$ & 278 & - & - & - & 5 & - & 150 & $\mathrm{D}(\mathbf{1})^{*}$ & No & $\begin{array}{l}\text { Chronic lymphatic } \\
\text { leukeamial hydronephro- } \\
\text { sis; bronchopneumonia; }\end{array}$ \\
\hline 55 & $89 \mathrm{M}$. & $28 \cdot 3$ & 12 & 160 & 90 & $3 \cdot 2$ & 251 & - & - & - & 6 & - & 90 & D (1) & No & $\begin{array}{l}\mathrm{Hb} 10.2 \mathrm{~g} / 100 \mathrm{ml} \\
\text { Malnutrition; Hb } 6.3 \mathrm{gl} \\
\text { 100 mli lobar pneumonia; } \\
\text { chronic glomerulonephri- }\end{array}$ \\
\hline 56 & $89 \mathrm{M}$. & $28 \cdot 9$ & 16 & $<60$ & - & $<2 \cdot 0$ & 56 & - & - & - & 32 & - & 85 & $\mathrm{D}(7)$ & - & $\begin{array}{l}\text { tis; } \mathrm{H}_{2} \mathrm{O} \text { depletion } \\
\text { Congestive cardiac failure; } \\
\mathrm{Hb} 10.7 \mathrm{~g} / 100 \mathrm{ml} \text {; }\end{array}$ \\
\hline $\begin{array}{l}57 \\
58\end{array}$ & $\begin{array}{l}87 \mathrm{~F} \\
79 \mathrm{M} .\end{array}$ & $\begin{array}{l}29 \cdot 4 \\
29 \cdot 4\end{array}$ & Unknown & ${ }_{450}^{1,100(2) *}$ & $\overline{880}$ & $\begin{array}{l}2 \cdot 8 \\
2 \cdot 6\end{array}$ & $\begin{array}{r}40 \\
134\end{array}$ & $=$ & $=$ & $=$ & $\begin{array}{r}4 \\
10\end{array}$ & $=$ & N.R. & $\begin{array}{l}\mathrm{D}(1) \\
\mathrm{D}(1)\end{array}$ & $\overline{\mathrm{No}}$ & $\begin{array}{l}\text { pancytopenia } \\
\text { Treated pernicious anaemis } \\
\text { Treated congestive cardiac } \\
\text { fiater. }\end{array}$ \\
\hline $\begin{array}{l}59 \\
60\end{array}$ & $\begin{array}{ll}63 \mathrm{~F} \\
80 \mathrm{~F}\end{array}$ & $\begin{array}{r}<30.0 \\
30.0\end{array}$ & $\begin{array}{l}168 \\
336\end{array}$ & $\begin{array}{l}164 \\
360(3)\end{array}$ & $\begin{array}{l}110 \\
142\end{array}$ & $\begin{array}{l}2 \cdot 8 \\
1 \cdot 2\end{array}$ & $\begin{array}{l}52 \\
54\end{array}$ & $\overline{-}$ & $\overline{-}$ & $=$ & $\begin{array}{l}28 \\
24\end{array}$ & $\overline{-}$ & $\begin{array}{r}95 \\
110\end{array}$ & $\mathrm{D}_{\mathrm{R}}(7)$ & No & $\begin{array}{l}\text { faliure; ; } \mathrm{H}_{2} \mathrm{O} \text { depletion } \\
\text { Myxoedema } \\
\text { Treated pernicious anaemia }\end{array}$ \\
\hline 62 & $73 \mathrm{M}$. & $30 \cdot 0$ & Unknown & 100 & $<20$ & $2 \cdot 8$ & 283 & - & - & - & 19 & - & N.R. & $\mathbf{D}(\mathbf{1})$ & No & $\begin{array}{l}\text { K } 2.8 \mathrm{mmol} / \mathrm{l} \text {. } \\
\text { Congestive cardiac failure; } \\
\text { Hb } 11.8 \text { g/100 ml; } \\
\text { progressive renal failure; } \\
\text { K 7.4 mmollil. (renal } \\
\text { Carcinomatosis (renal } \\
\text { primary); bronchopneu- }\end{array}$ \\
\hline 63 & $69 \mathrm{M}$. & $31 \cdot 1$ & 24 & 75 & 134 & 3.5 & 61 & 7.15 & 46 & 103 & 14 & 17 & 110 & $\mathbf{R}$ & - & $\begin{array}{l}\text { monia; K 6.5 mmoll.1. } \\
\text { Cerebrovascular disease; } \\
\text { ? + ethanol,? + CO }\end{array}$ \\
\hline 64 & $71 \mathrm{~F}$ & $32 \cdot 0$ & 12 & 184 & 142 & 2.8 & 174 & 7.22 & 25 & 28 & 11 & 17 & 95 & D (1) & No & $\begin{array}{l}\text { poisoning } \\
\text { Recent myocardial } \\
\text { infarction; pulmonary } \\
\text { embolus + oedema; } \\
\text { fatty kidneys dementia; } \\
\text { Hb } 10 \cdot 3 \text { g/100 ml; }\end{array}$ \\
\hline 65 & $72 \mathrm{M}$. & $32 \cdot 2$ & 72 & 600 & 75 & 3.5 & 120 & 7.22 & 20 & 80 & 12 & 19 & 100 & $D(5)$ & - & $\begin{array}{l}\text { K } 8.0 \text { mmol/l. } \\
\text { Thrombocytopenia; } \\
\text { progressive abdominal } \\
\text { distension ? cause; }\end{array}$ \\
\hline 66 & $80 \mathrm{M}$. & 33.0 & 18 & $<60$ & - & 2.7 & 305 & - & - & - & $<5$ & - & 100 & $\mathrm{D}(1)$ & No & $\begin{array}{l}\text { K 2.7 mmol//1. } \\
\text { Chronic alcoholism, } \\
\text { cirrhosis; acute myocar- } \\
\text { dial infarction + fibrosis; } \\
\text { pulmonary oedema; } \\
\text { pulmonary infarction; } \\
\text { pleural effusions; } \\
\text { cerebral softening; }\end{array}$ \\
\hline 68 & $78 \mathrm{~F}$ & 33.3 & 240 & $129(2)$ & 105 & $<2 \cdot 0$ & 104 & 7.35 & - & 46 & 24 & - & 100 & D (7) & Yes & $\begin{array}{l}\text { K 7.2 mmoli/l. } \\
\text { Acute parotitis; congestive } \\
\text { cardiac failure; pulmonary } \\
\text { oedema; bronchopneu- } \\
\text { monia; cerebral softening; } \\
\text { bilateral adrenal medullary } \\
\text { haemorrhages mes mediac filure } \\
\text { Congestive cardiac failure; } \\
\text { paranoid state; } \\
\text { Hb } 5.4 \text { g/100 ml } \\
\text { (? Fe deficiency) }\end{array}$ \\
\hline $\begin{array}{l}\text { Mean } \\
1 \text { S.D. } \\
\begin{array}{l} \pm .+ \\
\text { M. }\end{array} \\
\text { F. }\end{array}$ & $\begin{array}{l}76 \pm 8 \\
79 \div 8 \\
74 \pm 8\end{array}$ & \begin{tabular}{|l}
$30 \cdot 7+2 \cdot 1$ \\
$30 \cdot 4+1 \cdot 7$ \\
$30 \cdot 9+2 \cdot 5$
\end{tabular} & $\begin{array}{r}81+109 \\
28+25 \\
118 \pm 132\end{array}$ & $\begin{array}{l}275+274 \\
215+219 \\
328+320\end{array}$ & $\begin{array}{r}171+238 \\
259 \pm 348 \\
98 \pm 47\end{array}$ & \begin{tabular}{|l|}
$2.6 \pm 0.6$ \\
$2.9 \pm 0.5$ \\
$2.3 \pm 0.6$
\end{tabular} & $\begin{array}{l}139+95 \\
173+105 \\
109+81\end{array}$ & $\begin{array}{l}7.24+0.08 \\
7.19+0.05 \\
7.29 \pm 0.09\end{array}$ & $\begin{array}{l}34 \pm 13 \\
33 \div 18 \\
35 \pm 13\end{array}$ & $\begin{array}{l}64+34 \\
92+16 \\
37 \pm 13\end{array}$ & $\begin{array}{l}15+9 \\
12+9 \\
17 \pm 9\end{array}$ & $\begin{array}{l}14+8 \\
18+\frac{8}{+1} \\
10 \pm 11\end{array}$ & $\begin{array}{ll}91 & \pm 42 \\
96 \pm & 17 \\
86 & \pm 57\end{array}$ & 三 & 三 & \\
\hline
\end{tabular}

$\begin{aligned} & \text { *Figures in parentheses refer to days after admission or day of tes. } \\ & \text { N.R. }\end{aligned}=$ Not recordable, taken as zero.

N.R. $=$ Not recordable,
R/D $=$ Recovered $/$ died.

TABLE III-Mean Clinical and Biochemical Values $( \pm 1 S D)$ for whole Series

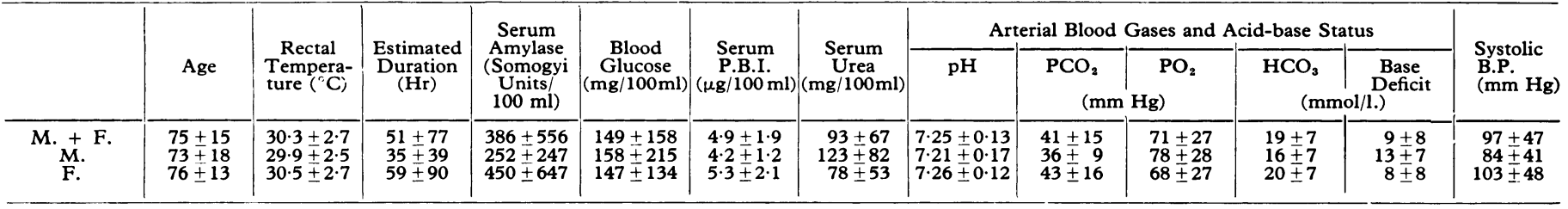

within the first week of admission to hospital (422 \pm 627$)$ was greater than in those who survived this period (348 \pm 477 ), but this difference was not significant.

The blood glucose level, determined in 51 patients, was raised (greater than $120 \mathrm{mg} / 100 \mathrm{ml}$ ) in 16 of the 40 patients who were euthyroid and 4 of the 11 with myxoedema. There was a significant correlation between the serum amylase and blood glucose levels $(P<0.001)$ but not between the blood glucose levels and the patients' temperatures. Low blood sugar levels (less than $80 \mathrm{mg} / 100 \mathrm{ml}$ ) were found in 12 patients, including three with myxoedema.

Only patients with blood glucose levels either in excess of $250 \mathrm{mg} / 100 \mathrm{ml}$ or of $40 \mathrm{mg} / 100 \mathrm{ml}$ or less were considered for treatment of this aspect of their illness. One patient (case 25; blood glucose $265 \mathrm{mg} / 100 \mathrm{ml}$ ) received intravenous saline but no insulin and recovered without further manifest glucose intolerance. In case 3 (blood glucose $336 \mathrm{mg} / 100 \mathrm{ml}$ ) the patient had sustained a massive intracerebral haemorrhage and so was not treated. In case 23 the patient was found to have a blood glucose of $600 \mathrm{mg} / 100 \mathrm{ml}$ with ketoacidosis on the fourth day after admission to hospital and after becoming euthermic. She required insulin until her death four weeks later. A known diabetic previously treated with chlorpropamide (case 46 ) had a blood glucose level of $670 \mathrm{mg} / 100 \mathrm{ml}$ and required 300 units of soluble insulin during the 24 hours before she became euthermic and her diabetic ketoacidosis was corrected; her insulin requirements remained high. She also received intravenous saline, pot- assium, and alkali while hypothermic. In case 58 the patient was given 100 units of soluble insulin and intragastric normal saline but died from acute severe pulmonary oedema before his diabetic ketoacidosis was corrected. Half of each dose of soluble insulin was always given intravenously and half by deep intramuscular injection.

Of the six patients with severe hypoglycaemia three (cases 34, 45 , and 62 ) had malignant disease and so were not given glucose. One patient (case 52 ; blood glucose $13 \mathrm{mg} / 100 \mathrm{ml}$ ) was given $20 \mathrm{ml}$ of $20 \%$ glucose solution intravenously and recovered. A further patient (case 10; blood glucose $40 \mathrm{mg} / 100 \mathrm{ml}$ ) died despite receiving the same treatment but at necropsy he was found to have peritonitis secondary to perforation of an acute duodenal ulcer. In case 33, despite a blood glucose level of less than $10 \mathrm{mg} / 100 \mathrm{ml}$, the patient was given 16 units of soluble insulin intravenously as part of her emergency treatment for hyperkalaemia, but she was simultaneously given $20 \mathrm{ml}$ of $25 \%$ glucose solution intravenously and regular glucose drinks thereafter. She survived for almost a week.

\section{Discussion}

In euthermic patients serum amylase levels greater than $\mathbf{5 5 0}$ Somogyi units $/ 100 \mathrm{ml}$ strongly support a diagnosis of acute pancreatitis, and levels of greater than 2,000 Somogyi units/ $100 \mathrm{ml}$ are sometimes reached within 24 hours of its onset. In 
most patients the level returns to normal within $48-72$ hours but occasionally high values persist for a week. Serum amylase values of $800-2,000$ Somogyi units $/ 100 \mathrm{ml}$ may also occur transiently when secondary pancreatic damage results from acute disturbances of adjacent organs, such as perforated gastric or duodenal ulcers, gastric operations, small-intestinal strangulation or obstruction, stones in the common bile duct or morphine-induced spasm of the sphincter of Oddi, empyema of the gall bladder, and dissection of the wall of the abdominal aorta (Wilkinson, 1962).

In the absence of pancreatic disease bacterial and mumps parotitis commonly lead to serum amylase values of up to 900 Somogyi units $/ 100 \mathrm{ml}$ but their clinical recognition is easy. Serum levels of up to 1,600 Somogyi units $/ 100 \mathrm{ml}$ have occasionally been associated with blood urea levels of $500-600 \mathrm{mg} / 100 \mathrm{ml}$, but one large study of uraemic patients failed to show any significantly raised serum amylase levels (Wilkinson, 1962). Part of the serum content of amylase is probably derived from tissues such as the liver, striated muscle, and the Fallopian tubes, since the experimental removal of the pancreas and salivary glands in animals fails to alter significantly the normal serum level of the enzyme (Wilkinson, 1962).

The raised serum amylase levels found in our patients with accidental hypothermia and hypothermic myxoedema probably mostly reflected a mild degree of acute pancreatitis, though clearly this may not have been the whole explanation. One patient, for example, had acute necrotizing parotitis, but this complication was probably one facet of her general debilitated state rather than a specific effect of hypothermia. A number of patients had other upper gastointestinal tract lesions capable of causing secondary acute pancreatitis. Our findings confirm that impaired renal function, which was common, plays no part in the raised serum amylase levels found. It is possible that other tissues such as striated muscle may release amylase into the serum during hypothermia, since earlier work has shown large increases in the serum levels of the muscle enzymes creatine kinase, " $\alpha$-hydroxybutyrate dehydrogenase," and aspartate aminotransferase (Maclean et al., 1968). The liver is unlikely to be a major source of the amylase since alanine aminotransferase levels are only minimally raised in patients with accidental hypothermia and hypothermic myxoedema (Maclean et al., 1968).

The necropsy rate in this series was low and raised serum amylase levels were not always associated with the finding of acute pancreatitis at necropsy-for example, cases 13 and 58. This finding has been noted previously (Duguid et al., 1961). When present at necropsy the pancreatitis ranged from being mild with focal areas of haemorrhagic destruction of the gland, with or without fat necrosis in the adjacent tissues, to widespread destruction of the gland with abscess formation, as in case 23 .

The mechanism behind these findings is unknown and many factors may contribute to them. The pancreatic damage does not appear to represent a direct cold injury to the gland. When the series as a whole was divided into the three generally accepted levels of severity of hypothermia $-32 \cdot 2^{\circ} \mathrm{C}$ and above (16 patients), $32.1-26 \cdot 7^{\circ} \mathrm{C}$ (48 patients), and $26 \cdot 6^{\circ} \mathrm{C}$ and below (4 patients)-there appeared to be no correlation with the mean ( \pm 1 S.D.) amylase levels $-343 \pm 341,414 \pm 630$, and $218 \pm$ 192 Somogyi units $/ 100 \mathrm{ml}$ respectively. This is confirmed by our finding no significant correlation between the amylase levels and either the patient's lowest recorded rectal temperature or the estimated duration of the hypothermia.

Arterial hypoxia, hypercapnia, and a base deficit do correlate with the raised amylase levels but the precise explanation is conjectural. One critical point at issue is whether or not during hypothermia the tissues receive enough oxygen to meet their demand (Cooper and Ross, 1960). In both animals and man, during cooling to $15^{\circ} \mathrm{C}$ the oxyhaemoglobin dissociation curve moves so far to the left that at normal arterial blood and tissue oxygen and carbon dioxide tensions haemoglobin binds its oxygen so tenaciously that this oxygen may be unable to meet tissue oxygen demands (Brown and Hill, 1923; Lange et al., 1949; Penrod, 1951; Cooper and Ross, 1960; Callaghan et al., 1961 ; Keatinge, 1969). Under these circumstances haemoglobin may give up its oxygen only when exposed to a $\mathrm{Po}_{2}$ considerably less than normal (Cooper and Ross, 1960), and the oxygen in physical solution in the plasma may then become of increasing importance as a source of tissue oxygen (Callaghan et al., 1961). Cooper and Ross (1960) believe that estimated tissue $\mathrm{Po}_{2}$ levels during hypothermia are probably low enough to allow the tissues to extract sufficient oxygen from the oxyhaemoglobin despite the extreme shift to the left in the oxyhaemoglobin dissociation curve.

The dissociation of oxyhaemoglobin may be encouraged by a rise in arterial $\mathrm{PCO}_{2}$ levels, since this shifts the oxyhaemoglobin dissociation curve to the right and also flattens its shape, thus opposing the effects of hypothermia (Lange et al., 1949; Callaghan et al., 1961). This makes less attractive the hypothesis that tissue hypoxia has an important role. Moreover, though there may be an initial rise during the early stages of hypothermia (Adolph, 1950) tissue oxygen consumption generally falls progressively and in proportion to the fall in body temperature (Fuhrman and Crismon, 1947; Adolph, 1950, 1956; Horvath et al., 1953; Edwards et al., 1954; Lougheed et al., 1955; Stone et al., 1956; Cooper and Ross, 1960) in all metabolizing cells except possibly the liver (Fuhrman and Crismon, 1947). In man, for example, oxygen consumption falls by about $26 \%$ over the temperature range $34-30^{\circ} \mathrm{C}$ (Michenfelder et al., 1965). There is no evidence that essential oxidative enzyme processes, which are responsible for energy metabolism in the cells, are inactivated during hypothermia (Adolph, 1956; Cooper and Ross, 1960; Keatinge, 1969).

The raised arterial $\mathrm{PCO}_{2}$ levels and the base deficits might contribute to pancreatic cell injury through the common mechanism of acidosis, but there was no significant correlation between the serum amylase and the arterial blood pH levels.

Duguid et al. (1961) suggested that intravascular sludging might play a part in the causation of the lesions found in hypothermic patients, but we found no correlation between high serum amylase levels and a low systolic blood pressure. Other work on this problem is currently being undertaken and the evidence so far suggests that intravascular sludging may not be a major contributory factor.

Several practical aspects deserve to be emphasized. Acute pancreatitis is common in patients with accidental hypothermia and hypothermic myxoedema. It is usually mild but even when severe it is not accompanied by signs of an acute intra-abdominal emergency and does not directly affect the patient's chances of survival. Those patients dying within one week of their admission to hospital had a mean amylase value ( \pm 1 S.D.) of $422 \pm$ 627 Somogyi units $/ 100 \mathrm{ml}$, whereas those surviving beyond this time had a mean value of $348 \pm 477$ Somogyi units $/ 100 \mathrm{ml}$; this difference is not significant. Likewise, those patients with hypothermic myxoedema did not have a more severe form of acute pancreatitis, so that the pancreatitis does not contribute to the poorer prognosis in these cases.

The significant correlation between the serum amylase and blood glucose levels was the most important finding, since four patients had diabetic ketoacidosis on admission and in another its recognition was delayed for several days after that of the raised amylase level. The pancreatic damage presumably augments further the drop in insulin production which occurs as a direct result of the hypothermia, and the cold also decreases its effectiveness (Cooper and Ross, 1960). At body temperatures of $31-21^{\circ} \mathrm{C}$ even very large doses of insulin may have little effect on reducing high blood glucose levels (Wynn, 1956; Cooper and Ross, 1960). When a hypothermic patient with hyperglycaemia suffers from diabetes mellitus, therefore, some workers consider it advisable to raise the body temperature rapidly to $31-32^{\circ} \mathrm{C}$ before giving insulin (Cooper, 1968). Where appropriate this complication merits treatment in its own right. In one of our patients, a chlorpropamide-controlled diabetic, high doses of 
soluble insulin were required to control her diabetic ketoacidosis.

When the hypothermic patient with hyperglycaemia does not have diabetes mellitus insulin may not be required, as normoglycaemia is spontaneously restored during or soon after rewarming (Prescott et al., 1962), as occurred in case 25. Our experience suggests that most euthyroid and some hypothyroid hypothermic patients rewarm spontaneously at satisfactory rates (Maclean et al., 1973), so that when insulin is given to hypothermic patients the start of this therapy can be delayed until the body temperature is above $32^{\circ} \mathrm{C}$. After this care should be taken not to give unnecessarily high doses, and the blood sugar should be monitored regularly to detect any tendency toward the development of hypoglycaemia during or soon after rewarming as the effectiveness of the administered insulin increases.

Though even grossly raised serum amylase levels may not in themselves be associated with increased mortality or morbidity (Knight et al., 1973) all patients with accidental hypothermia and hypothermic myxoedema should have their serum amylase and blood glucose levels measured soon after admission to hospital. Not only will this indicate diabetic ketoacidosis when it is present but raised amylase levels will identify patients likely to develop diabetic ketoacidosis in the ensuing few days. Unsuspected hypoglycaemia, with its signs masked by the hypothermic state (Duckworth and Cooper, 1964; Hockaday and Fell, 1969), will also be detected. Its correction may contribute to the patient's recovery (Roe, 1963; Jones et al., 1966) and sometimes leads to the immediate restoration of consciousness (Whittaker and Whitehead, 1954; Murphy and Faul, 1963; Duckworth and Cooper, 1964). Arterial blood gas estimations may further help to identify the hypothermic patient at risk of developing pancreatitis.

We thank our laboratory staffs and the physicians of the Dundee teaching hospitals for their help and co-operation.

\section{References}

Adolph, E. F. (1950). American fournal of Physiology, 161, 359

Adolph, E. F. (1956). In Physiology of Induced Hypothermia, ed. R. D. Dripps, p. 44. Washington, National Academy of Sciences-National Research Council.

Alexander, L. (1945). Cited by Gagge and Herrington (1947).

Baum, D., and Porte, D. (1971). American fournal of Physiology, 221, 303. Brown, W. E. L., and Hill, A. V. (1922/1923). Proceedings of the Royal Society of London, Series B, 94, 297.

Callaghan, P. B., Lister, J., Paton, B. C., and Swan, H. (1961). Annals of Surgery, 154, 903.
Cooper, K. E. (1968). In Recent Advances in Medicine, ed. D. N. Baron, N. Compson and A. M. Dawson, 15th edn., chap. 11, p. 343. London, Churchill.

Cooper, K. E., and Ross, D. N. (1960). Hypothermia in Surgical Practice. London, Cassell.

Curry, D. L., and Curry, K. P. (1970). Endocrinology, 87, 750.

Duckworth, W. C., and Cooper, B. C. (1964). South African Medical fournal, 38, 295.

Duguid, H., Simpson, R. G., and Stowers, J. M. (1961). Lancet, 2, 1213.

Edwards, W. S., Tuluy, S., Reber, W. E., Siegel, A., and Bing, R. J. (1954). Annals of Surgery, 139, 275.

Emslie-Smith, D. (1958). Lancet, 2, 492.

Fruehan, A. E. (1960). Archives of Internal Medicine, 106, 218.

Fuhrman, F. A., and Crismon, J. M. (1947). American fournal of Physiology, $149,552$.

Gagge, A. P., and Herrington, L. P. (1947). Annual Review of Physiology,

Hockaday, T. D. R., and Fell, R. H. (1969). British Fournal of Hospital

Medicine, 2, 1083.
Holmes, R., and Emslie-Smith, D. (1961). Lancet, 1, 1002.

Horvath, S. M., Hutt, B. K., Spurr, G. B., and Stevens, G. E. (1953). Science, 118, 100.

Jones, R. H. T., Bourdillon, R. E., Finn, R., and Martindale, K. (1966). Postgraduate Medical fournal, 42, 273.

Keatinge, W. R. (1969). Survival in Cold Water, p. 63. Oxford, Blackwell.

King, J. (1965). Practical Clinical Enzymology, chap. 6, p. 208. London, Van Nostrand.

Knight, A. H., Williams, D. N., Ellis, G., and Goldberg, D. M. (1973). British Medical fournal, 3, 128.

Lange, K., Weiner, D., and Gold, M. M. A. (1949). Annals of Internal Medicien, 31, 989.

Laufman, H. (1951). Fournal of the American Medical Association, 147, 1201.

Lougheed, W. M., Sweet, W. H., White, J. C., and Brewster, W. R. (1955). Fournal of Neurosurgery, 12, 240.

McKean, W. I., Dixon, S. R., Gwynne, J. F., and Irvine, R. O. H. (1970). British Medical fournal, 2, 463.

Maclean, D., Griffiths, P. D., and Emslie-Smith, D. (1968). Lancet, 2, 1266

Maclean, D., Taig, D. R., and Emslie-Smith, D. (1973). British Medical fournal, 2,87

Mant, A. K. (1969). British fournal of Hospital Medicine, 2, 1095.

Michenfelder, J. D., Uihlein, A., Daw, E. F., and Theye, R. A. (1965). British fournal of Anaesthesia, 37, 738 .

Murphy, E., and Faul, P. J. (1963). Fournal of the Irish Medical Association, $53,4$.

53, 4. Kenrod, E. (1951). American fournal of Physiology, 164, 79.

Penrod, K. E. (1951). American fournal of Physiology, 164, 79. Journai, F., Peard,

Read, A. E., Emslie-Smith, D., Gough, K. R., and Holmes, R. (1961). Lancet, 2, 1219.

Roe, P. F. (1963). Irish fournal of Medical Science, 454, 459.

Sano, M. E., and Smith, L. W. (1940). Fournal of Laboratory and Clinical Medicine, 26, 443.

Smith, L. W. (1940). Archives of Pathology, 30, 424.

Soler, N. G., Bennett, M. A., FitzGerald, M. G., and Malins, J. M. (1973). Lancet, 1,951 .

Sprunt, J. G., Maclean, D., and Browning, M. C. K. (1970). Lancet,1, 324.

Stone, H. H., Donnelly, C., and Frobese, A. S. (1956). Surgery, Gynecology and Obstetrics, 103, 313.

Street, H. V., and Close, J. R. (1956). Clinica Chimica Acta, 1, 256.
Street, H. V., and Close, J. R. (1958). Clinica Chimica Acta, 3, 476.

Street, H. V., and Close, J. R. (1958). Clinica Chimica Acta, 3, 476. 2,265 .

Wilkinson, J. H. (1962). Introduction to Diagnostic Enzymology, p. 62. London

Arnold.
Wynn, V. (1956). Clinical Science, 15, 297. 